\title{
FDI Inflow Determinants in BRIC countries: A Panel Data Analysis
}

\author{
Vinit Ranjan \\ ABV-Indian Institute of Information Technology and Management \\ Gwalior, India - 474010 \\ E-mail: vinit.iiitm@gmail.com \\ Dr. Gaurav Agrawal \\ Assistant Professor, ABV-Indian Institute of Information Technology and Management \\ Gwalior, India - 474010 \\ E-mail: gauravagrawal@iiitm.ac.in
}

Received: April 28, 2011

Accepted: May 18, 2011

doi:10.5539/ibr.v4n4p255

\begin{abstract}
This study explores Foreign Direct Investment (FDI) inflow determinants in Brazil, Russia Federation, India and China; collectively known as BRIC countries. A random effect model is employed on the panel data set consisting of annual frequency data of 35 years ranging from 1975 to 2009 to identify the FDI inflow determinants. The empirical results show that market size, trade openness, labour cost, infrastructure facilities and macroeconomic stability and growth prospects are potential determinants of FDI inflow in BRIC where as gross capital formation and labour force are insignificant, although macroeconomic stability and growth prospects have very little impact.
\end{abstract}

Keywords: Foreign Direct Investment, BRIC, Panel Data, Macroeconomic factors

\section{Introduction}

Trade has always been a vital part of economy and with the concept of globalization it reaches to the international level. The role of Foreign Direct Investment (FDI) in this development is very crucial. The enormous increase in FDI flows across countries is one of the clearest signs of the globalization of the world economy over the past 20 years (UNCTAD, 2006). According to UNCTAD Foreign direct investment (FDI) is defined as an investment involving a long-term relationship and reflecting a lasting interest in and control by a resident entity in one economy (foreign direct investor or parent enterprise) of an enterprise resident in a different economy (FDI enterprise or affiliate enterprise or foreign affiliate). Such investment involves both the initial transaction between the two entities and all subsequent transactions between them and among foreign affiliates. FDI has innumerable effects on the host country's economy. It influences the income, production, prices, employment, economic growth, development and general welfare of the recipient country. FDI are the most significant channels for the dissemination of modern technology (Blomstrom, 1989). So, we can say that FDI plays a key role in development of emerging economy because the very essence of economic development is the rapid and efficient transfer and adoption of "best practice" across borders.

In last two three decades world has experienced a massive change in terms of geopolitics, economics and in organisation and distribution of production. For several reasons, emerging economies of Brazil, Russia, India and China (BRIC) have acquired important role in the world economy as producers of goods and services. All the four countries of BRIC have common characteristic of large population, potential consumer market, fast economic growth, big land size etc, on the basis of which they are attracting large amount of investors around the world. The BRICs, with 40 percent of the world's population spread out over three continents, already account for 25 percent of global GDP (IMF article "BRICs Drive Global Economic Recovery", july 22, 2009). The combined economies of Brazil, Russia, India and China (BRICs) appear likely to become the largest global economic group by the middle of this century." (Cheng, Gutierrez, Mahajan, Shachmurove, and Shahrokhi, 2007). Goldman Sachs predicted that China and India are likely to emerge as dominant global suppliers of manufactured goods and services while Brazil and Russia to dominate in supply of raw materials. Currently BRICs are the world's four leading emerging market economies, the nominal GDP of which reached 10.67 trillion US dollars in 2010. According to World Bank Database, between 2000 to 2008 FDIs net inflow (BoP, current US \$) grew from $\$ 77.47$ billion to $\$ 309.16$ billion representing a compounded annual growth rate of $18.88 \%$.

China, by far the leading market destination of FDI received US\$147.79 billion inflows in 2008 where as Russia, Brazil and India attracts US\$75, US\$45.05 and US\$41.31 billion respectively. China and India are emerging as the most important economic driving forces in the world. The two Asian giants have $40 \%$ of the lobal labor force and $18 \%$ of the world economy in terms of purchasing power parity (PPP). According to A. T. Kearney's 2005 FDI Confidence 
Index, China maintained its position as the most attractive FDI destination globally for a fourth year in a row, with India in second place, rising from fifteenth in 2002. Following substantial increases during 2004-2008, FDI flows to the Russian Federation is at about US\$ 37.62 .8 billion on average during the following five years. Compared the size of the Russian economy with the volume of flows to other countries in Central and Eastern Europe, the level of FDI in Russia is relatively low, suggesting that FDI in the country is still at an early stage (World Investment Directory online). Brazil, which has traditionally fallen behind of other three in attracting FDI due to its size and resource endowment, doubled its inward foreign direct investment between 2006 and 2007 (US\$18.8 billion to 34.58 billion).

After 2008, the world has been stuck in the turmoil of financial crisis. The BRICs are certainly not wholly immune to the economic decline of the US, whose sub-prime mortgage crisis has triggered the turmoil in global financial markets. A sharp decrease in FDI inflow in figure 1.1 and 1.2 tells the story. But unlike the US and many other developed countries, the BRICs (Brazil, Russia, India and China) appear well positioned to weather the global economic downturn.

Based on newly revised GDP growth projections, IMF (International Monetary Fund) has anticipated a modest declaration of BRIC's amazing growth path. According to IMF, BRIC countries have a share of $46.3 \%$ of global GDP growth (based on purchasing power parity, in \$) in 2000-20008, where as G7 countries contribution is only $19.8 \%$. These differences raise interesting questions for both academia and policymakers as to why the BRIC countries have performed differently in attracting inward FDI. What is determining the FDI flows into the BRIC countries? Will BRIC continue an increasing trend of receiving FDI? These questions need to be addressed from both theoretical and empirical perspectives.

In this context, present study is intended to determine the major determinants that show the capital flow to BRIC countries in a globalization framework. The aim is to provide a much more robust and generalized empirical analysis and conclusions by employing large panel-data over a long time period. The rest of the study is organized as follows. Section 2 presents a brief review of literature; Section 3 discusses the FDI determinant theory and structure hypothesis; Section 4 narrates the methodology and data used in the paper; Section 5 explains the findings and the empirical analysis and finally Section 6 provides conclusion of the study.

\section{Literature Review}

The classical model for determinants of FDI begins from the earlier research work of Dunning $(1973,1981)$ which provide a comprehensive analysis based on ownership, location and the internationalization (OLI) paradigm. Duran (1999) uses the Panel data and time series techniques to find out the drivers of FDI for the period 1970-1995. The study indicates that the size, growth, domestic savings, country's solvency, trade openness and macroeconomic stability variables are the catalysts of FDI. Beven and Estrin (2000) establish the determinants of FDI inflows to transition economies (Central and Eastern Europe) by taking determinant factors as country risk, labour cost, host market size and gravity factors from 1994 to1998. The study observes that country risks are influenced by private sector development, Industrial development, the government balance, reserves and corruption. Garibaldi et al (2002) analyse the FDI and Portfolio investment flows to 26 transition economies in Eastern Europe including the former Soviet Union from 1990 to 1999. The regression estimation indicates that the FDI flows are well explained by standard economic fundamentals such as market size, fiscal deficit, inflation and exchange rate regime, risk analysis, economic reforms, trade openness, availability of natural resources, barriers to investments and bureaucracy.

While some of these studies conclude that there are growth benefits associated with FDI, many tend to find no effects or limited effects (results that are not robust across alternative specifications) through traditional channels such as capital accumulation for developing countries (Kose at al., 2009a).Sound macroeconomic policies can create a general stimulus for FDI spillovers to domestic investment by raising the marginal product of new investments and creating an enabling environment for technology diffusion (Mody and Murshid, 2005)

Since previous papers indicates mixed results and doesn't provide any significant aggregate information about the determinants related to FDI in BRIC countries, present study focuses on the aggregate empirical analysis of determinants of FDI in BRICs in the view of major country level events. The period of the study has been taken from 1975 to 2009.

\section{Potential Variables Determining FDI Inflows}

Based on the literature review, this study reckons a set of potential determinant variables that influence the FDI inflows and classify the variables into six broad categories, viz., Market size, Economic stability and Growth prospects, Trade openness, Infrastructure facilities, Labour cost and Gross capital formation. This classification has resemblance with the classification of FDI determinants by UNCTAD presented in table 3.1.

\section{Market Size}

Large consumer market means more potential of consumption and thus more opportunity for trade. Countries having larger consumer market should receive more inflows than that of smaller countries. Market size is generally measured 
by Gross Domestic Product (GDP), GDP per capita income and size of the middle class population. It is expected to be a positive and significant determinant of FDI flows (Lankes and Venables, 1996; Resmini, 2000; Duran, 1999; Garibaldi, 2002; Bevan and Estrin, 2000; Nunes et al., 2006; Sahoo, 2006). In contrast, Holland and Pain (1998) and Asiedu (2002) capture growth and market size as insignificant determinants of FDI flow.

H1: Larger market size of the host country attracts more FDI.

\section{Economic stability and Growth prospects}

Higher market growth indicates a potential larger market and more promising prospects. FDI, therefore, tends to flow to the countries with larger market size and higher economic growth rates in which larger economies of scale could be provided for FDI to exploit their ownership advantages (Culem, 1988). A country which has a stable macroeconomic condition with high and sustained growth rates will receive more FDI inflows than a more volatile economy. The proxies measuring growth rate are: GDP growth rates, Industrial production index, Interest rates, Inflation rates (Duran, 1999; Dassgupta and Ratha, 2000).

H2: Stable macroeconomic condition with high and sustained growth rates attract FDI to the host country.

\section{Trade openness}

Numerous empirical studies suggest that trade (imports and exports) complements rather than substitutes for FDI. Multinational enterprises (MNEs) tend to invest in the trade partner markets with which they are familiar. Much of FDI is export oriented and may also require the import of complementary, intermediate and capital goods. In either case, volume of trade is enhanced and thus trade openness is generally expected to be a positive and significant determinant of FDI (Lankes and Venables, 1996; Holland and Pain, 1998; Asiedu, 2002; Sahoo, 2006). Trade openness is proxied as the ratio of the Export plus Import divided by GDP (Nunes et al. 2006; and Sahoo, 2006).

H3: More liberal policies and trade facilities presents opportunity for FDI to come to the hosting country.

\section{Infrastructure facilities}

Well established and advance infrastructure facility narrates about the prosperity of the country and provides opportunity for FDIs. On the other hand, a country which has opportunity to attract FDI flows will stimulate a country to equip with good Infrastructure facilities. So the chance of positive effect of infrastructure facility on FDI inflow can not be denied.

H4: An established and advance infrastructure facility of the host country provides great platform for investment and leads to greater FDI inflow.

\section{Labour cost}

Higher labour cost in the home country is expected to pull the FDIs to host country. Higher labour cost makes the cost of production high and thus leads to FDI outflow or less FDI inflow. Labour cost can be proxied by wage rate (Lankes and Venables, 1996; Nunes et al 2006).

H5: Lower labour cost in the host country pulls FDI to the country.

\section{Gross capital formation}

Higher Gross capital formation leads to greater economic growth which is result of improvements in the investment climate which further helps to attract higher FDI inflows. Libor Krkoska (2001) and Lipsey (2000) find little evidence of FDI having an impact on capital formation in developed countries and observe that the most important aspect of FDI in the selected sample of countries is related to ownership change. However, a positive or negative and significant relationship between FDI and Capital Formation is expected.

H6: High Gross capital formation shows the potential of the country for spending and thus has a significant impact on FDI inflow.

So, the present study has following six hypotheses:

H1: Larger market size of the host country attracts more FDI.

H2: Stable macroeconomic condition with high and sustained growth rates attract FDI to the host country.

H3: More liberal policies and trade facilities presents opportunity for FDI to come to the hosting country.

H4: An established and advance infrastructure facility of the host country provides great platform for investment and leads to greater FDI inflow.

H5: Lower labour cost in the host country pulls FDI to the country.

H6: High Gross capital formation shows the potential of the country for spending and thus has a significant impact on FDI inflow.

\section{Data and Methodology}


The study is based on secondary data collected from the World Bank Indicator (WDI DATABANK) 2010. Frequency of the data is annual and it is from 1975 to 2009 for all the constituent countries of BRIC (except for Russia, where dataset distribution is from 1990, due to unavailability of data). The dependent variables in this study (in all four countries) is Log of FDI net inflow (BoP in current USD) and the independent variables that are expected to determine FDI flows are carefully chosen, based on previous literature and availability of dataset for the selected period. The independent variables in this estimation are:

- GDP (in current US\$)

- Inflation w.r.t CPI

- Labour Cost

- Trade Openness

- Infrastructure Index

- Work Force

- Gross Capital Formation

The Infrastructure index (INFREX) is constructed by indexing Electric Power Consumption (kwh per capita), Energy use (kg of oil equivalent per capita) and Telephone lines, total. In this study other infrastructure variables are ignored due to non availability of data for selected countries for the study period.

Based on the hypothesis posed the estimated model is as follows:

$\mathrm{FDI}=\mathrm{f}$ (market size, economic stability and growth prospect, labour cost, infrastructure, trade openness, labour force, gross capital formation)

Equation (1) can be changed into mathematical form using log-linear model:

$\mathrm{LFDI}_{\mathrm{it}}=\alpha+\beta 1 \mathrm{LGDP}_{\mathrm{it}}+\beta 2 \mathrm{INFL}_{\mathrm{it}}+\beta 3 \mathrm{LWAGE}_{\mathrm{it}}+\beta 4 \mathrm{INFREX}_{\mathrm{it}}+\beta 5 \mathrm{TRAO}_{\mathrm{it}}+\beta 6 \mathrm{LLAB}_{\mathrm{it}}+\beta 7 \mathrm{LGCF}_{\mathrm{it}}+\mathrm{e}_{\mathrm{it}}$

Where,

$L F D I_{\mathrm{it}}$ is the log of net inflow of Foreign Direct Investment (BoP in current US\$) for country i at time $\mathrm{t}$.

$L G D P_{\mathrm{it}}$ is the log of Gross Domestic Product in current US\$ for country $\mathrm{i}$ at time $\mathrm{t}$ and is the measure of market size.

$I N F L_{\text {it }}$ is the Inflation Rate (Annual percent) for country $\mathrm{i}$ at time $\mathrm{t}$, which is the measures of Growth prospectus of a country.

$L W A G E_{\mathrm{it}}$ is the log of worker's remittances and compensation of employees received in US $\$$ for country $\mathrm{i}$ at time $\mathrm{t}$ and is the measure of Labour cost

INFREX $X_{i t}$ is the Infrastructure Index for country i at time t. Narayanamurthy, Perumal \& Chandra (2010) has given the method of calculating infrastructure index. The simple Infrastructure index is constructed for the selected countries as:

$\mathrm{Y}_{\mathrm{jt}}=X j t /(X j t-1) \times 100$

Where $X j t$ is the value of $j$ th indicator at time $t$ for each country

$Y j t$ is the transformed value (index in percent) of the jth indicator at time $\mathrm{t}$ for each country. Then the above Yjt is summed up and divided by three to arrive at the Infrastructure Index in percent for each country i (INFREXi), which is presented as:

$\operatorname{INFREX}_{\text {it }}=\sum_{j}^{3} Y j t / 3$

$T R A O_{i t}$ is the Trade Openness for country $i$ at time $t$ and is computed as ratio of import of Goods and Services plus Export of Goods and Services divided by GDP

$L L A B_{i t}$ is the log of total labour force for country $\mathrm{i}$ at time $\mathrm{t}$.

$L G C F_{i t}$ is the log of gross capital formation (\% of GDP) for country i at time t.

$e_{i t}$ is the error term over the time t.

\subsection{Data Analysis Tools}

Panel Data Analysis: The panel data estimation is employed in the study to capture the dynamic behaviour of the parameters and to provide more efficient estimation and information of the parameters. Panel data techniques are used because of their advantages over cross-section and time series in using all the information available, which are not detectable in pure cross-sections or in pure time series [Baltagi and Kao (2000)]. Hsiao $(1985,1986)$ and Baltagi (1995) argued, panel data sets possess several major advantages. Panel data suggest individual heterogeneity to 
reduce the risk of obtaining biased results and provide a large number of data points (observations) to increase the degrees of freedom and variability and to be able to study the dynamics of adjustment.

The Panel data model includes three different methods:

- Random effects method: The Random effects method is an alternative method of estimation which handles the constants for each section as random parameters rather than fixed. Under this model, the intercepts for each cross-sectional unit are assumed to arise from a common intercept $\alpha$ (which is the same for all cross-sectional units and over time), plus a random variable $\epsilon_{\mathrm{i}}$ that varies cross-sectionally but is constant over time. $\epsilon_{\mathrm{i}}$ measures the random deviation of each entity's intercept term from the 'global' intercept term $\alpha$. We can write the random effects panel model as

$\mathrm{y}_{\mathrm{it}}=\alpha+\beta \mathrm{x}_{\mathrm{it}}+\omega_{\mathrm{it}}$

where,

$$
\omega_{\text {it }}=\epsilon_{\mathrm{i}}+\mathrm{v}_{\mathrm{it}}
$$

Here $\mathrm{x}_{\mathrm{it}}$ is still a $1 \times k$ vector of explanatory variables, but unlike the fixed effects model, there are no dummy variables to capture the heterogeneity (variation) in the cross-sectional dimension. Instead, this occurs via the $\epsilon_{i}$ terms. The parameters ( $\alpha$ and the $\beta$ vector) are estimated consistently, but instead of OLS, Generalised Least Square method (GLS) is used.

- Fixed effects method: The Fixed effects method treats the constant as group (section)-specific, i.e. it allows for different constants for each group (section). The Fixed effects also called as the Least Squares Dummy Variables (LSDV) estimators. The model for fixed effect method is

$\mathrm{y}_{\mathrm{it}}=\alpha+\beta \mathrm{x}_{\mathrm{it}}+\mu_{\mathrm{i}}+\mathrm{v}_{\mathrm{it}}$

where, $\mu_{\mathrm{i}}$ and $\mathrm{v}_{\mathrm{it}}$ are decomposition of disturbance term. $\mu_{\mathrm{i}}$ represents individual specific effect and $\mathrm{v}_{\mathrm{it}}$ represents 'remainder disturbance', that varies over time and entities (capturing everything that is left unexplained about $\mathrm{y}_{\mathrm{it}}$ ).

- Common constant method: Also called as pooled OLS method. This estimation presents result under the principal assumption that there are no differences among the data matrices of the cross sectional dimension $(\mathrm{N})$.

Generally in the panel data analysis, the fixed effects model assumes that each country differs in its intercept term, whereas the Random effects model assumes that each country differs in its error term. When the Panel is balanced (i.e., contains all existing cross sectional data), one might expect Fixed effects model to work well. Otherwise, the Random effect method will be more appropriate when the sample contains limited observations of the existing cross-sectional units.

Hausman Specification Test: The test evaluates the significance of an estimator versus an alternative estimator. It helps one evaluate if a statistical model corresponds to the data. This test compares the fixed versus random effects under the null hypothesis that the individual effects are uncorrelated with the other regressors in the model (Hausman 1978). If correlated (H0 is rejected), a random effect model produces biased estimators, violating one of the Gauss-Markov assumptions; so a fixed effect model is preferred.

\section{Empirical Results}

Present study uses Panel Data Analysis technique to estimate the dynamic behaviour of determinants of FDI inflow in Brazil, Russia, India and China. But before proceeding to estimate with panel data analysis, descriptive statistics and correlation analysis has been carried out. The outcomes of descriptive statistics and correlation analysis are tabled in table 5.1 and 5.2 respectively. All the variables are having range of 104 to 126 observations. The INFL has highest mean and standard deviation of 132.55 and 435.61 respectively in the data distribution. Standard deviation values of inflation indicate the presence of vast range of fluctuation of inflation in BRIC countries as in duration of 1981 to 1994 inflation rate touched four digit in Brazil (in 1994, 2075.88) and three digit in Russia (during 1993 to 1995).

From table 5.1, values of skewness and kurtosis indicate that GDP series is almost normal as its skewness value (0.14) is close to 0 and kurtosis value is 3. Correlation matrix indicates high correlation of LLAB with LGCF (0.81) and LWAGE (0.46). Variable TRAO is highly correlated with LGCF $(0.41)$ and LGDP $(0.53)$ and LGDP is highly correlated with LWAGE (0.58). The existence of high correlation among the independent variables will lead to the problem of multi-collinearity in the estimation. Still we consider these variables because of the statistical nature of panel data estimation which takes care of the collinearity problems. The estimates through Panel data analysis include OLS pooled regression (Common constant method) and Random effects method for the selected study period. Results are shown in table 5.3. From table it is clear that, the empirical results obtained from the pooled ordinary least squares (OLS) and the random effects (RE) are similar, so we choose Random effects model to check the robustness with Fixed effects model. Further the Fixed effects model is rejected in the analysis based on Hausman specification test (1978), the higher value of Hausman Test rejects the validity of Fixed effect model. 
The empirical results (Table 5.3) obtained from RE shows that regression model with dependent variable LFDI fits well with independent determinant variables as value of adjusted $R^{2}$ is significant $(0.77)$. High value of $R^{2}$ also indicates that the explanatory variables included in the equation can explain most of the variation in the dependent variable. Empirical results also support all the hypotheses but one, as all the explanatory variables have the right signs as expected, though some of them are not significant. The coefficient of gross domestic product (LGDP), labour cost (LWAGE) and trade openness (TRAO) are statistically significant at high level of $1 \%$, infrastructure index (INFREX) and inflation rate (INFL) are significant at 5\% level which shows that these determinants are potential determinants of FDI inflow where as gross capital formation (LGCF) and labour force (LLAB) are not significant which indicates that these determinants might not be important determinant in this case. The co-efficient signs for four out of seven variables are negative and are same as expected. Positive value indicates perfect synchronization of determinant variable with FDI inflow where as negative sign shows that they affect FDI inflow in reverse manner i.e. decreasing value of the determinant attracts more FDI to the BRIC countries.

The coefficient of market growth and trade openness, LGDP and TRAO shows that foreign investors are highly sensitive to market growth and trade openness as $1 \%$ increase in the variables leads to $2.89 \%$ and $1.04 \%$ increase in FDI respectively. Stable and advance infrastructure facilities also has slight positive impact on FDI as $1 \%$ increase in infrastructure index INFREX leads to $0.008 \%$ increase in FDI. BRIC countries' relatively bigger market size, quicker market growth and promising infrastructure have a significantly attractive effect on inward FDI. It can be argued that one of the important motives of FDI in China and India is market-seeking or tapping their large domestic markets.

Coefficient of labour cost indicates that $1 \%$ decrease in host countries' labour cost will lead to $0.49 \%$ increase in inflow of FDI. It is argued that higher value of labour cost in developed countries is a major factor for investors to search for lower labour cost destinations and thus they are highly attracted to BRIC countries where high population provides them lower labour cost.

Coefficient of inflation has negative relation with FDI inflow which supports the assumption but, its magnitude is very less so effect is not much of significance. In this study growth prospects are gauged by inflation and it suggest that slight boost in economy attracts FDI but the pulling power is not of high magnitude. Finally, gross capital formation (LGCF) and total labour force (LLAB) are negatively insignificant in determining the LFDI inflows, which might mean that they are not important considerations for foreign investors investing in BRIC countries. Thus empirical results provides the information that GDP, infrastructure index, trade openness and labour cost are potential determinants for the inflow of Foreign investors in BRIC countries where as total labour force and gross capital formation are not significant. So as a whole our all hypothesis is accepted except last one that is high gross capital formation should attract FDI as also mentioned in table 5.4.

\section{Summary and Conclusion}

The term BRICs puts under a common label the four largest fast growing emerging countries: Brazil, Russia, India and China. In recent days, these fast developing economies of the world having larger market potentials are expected to attract large inflow of FDI. However, the factors attracting the FDI inflows towards these countries are relatively less researched. This study made an attempt to identify the factors determining the FDI inflows of BRIC countries from the period 1975 to 2009. The determinant factors include: Market size, Economic Stability and Growth Prospects, Labour Cost, Infrastructure Facilities, Trade Openness, total labour force and Gross capital formation. The study finds that other than total labour force and gross capital formation (measured by log of total labour force LLAB and log of gross capital formation, $\%$ of GDP, LGCF respectively) all other factors seem to be the potential determinants of FDI inflows in BRICS countries.

The implications of empirical result seem consistent with the different perceptions of global investors on investment attributes of BRIC countries. Two of the BRIC countries India and China are most promising major economies. According to A. T. Kearney, 2005 China is cited as the world's manufacturing hub and fastest-growing consumer market, while India is known as the foremost business-processing and IT services hub with long-term market potential. On the other hand special trade openness facilities, geographical position and cheap labour cost are making Brazil a major destination for FDIs. Same is the case with Russia, its abundance resource of oil and gas are attracting hydrocarbon related FDIs and is also central hub for oil and gas import to Europe.

The challenge for the BRIC countries are how to sustain their performance and trend in FDI inflow and how to form their policy and optimize their economic condition to attract more FDIs in future. BRIC countries will have promising prospects for FDI inflows as their low labor cost, large market size and growth potential will remain as the key determinants and attractions for years.

Present study presents empirical results of determinants affecting FDI inflow in BRIC. However the study on determinants relating to the regional competency of the nations as well as equivalent to home countries of the foreign 
investors needs to be analysed further. Sectoral analysis is also expected to enhance the understanding of industry specific FDI flows and its associated determinants.

\section{References}

Asiedu, E. (2002). On the determinants of foreign direct investment developing counties: is Africa different?, World Development, $\quad$ Vol. $\quad 30 \quad$ (1). pp.107-119, doi:10.1016/S0305-750X(01)00100-0, http://dx.doi.org/10.1016/S0305-750X(01)00100-0

Baltagi, B. (1995). Econometric analysis of panel data, Chichester, UK:Wiley.

Baltagi, B.,H. \& Kao, C. (2000). Nonstationary panels, cointegration in panels and dynamic panels: a survey, Center for Policy Research, Working Paper, No. 16, Syracuse University, Syracuse, NY.

Bevan, A., A. and Estrin, S. (2000). Patterns of for eign direct investment and trade in central and eastern europe, mimeo.

Blomstrom, M. (1989). Foreign Investment and Spillovers: A Study of Technology Transfer to Mexico, Routledge, London.

Brooks, C. (2008). Introductory Econometric for finance, Cambridge University Press, New York, NY.

Cheng, H., F., Gutierrez, M., Mahajan, A., Shachmurove, Y., \& Shahrokhi, M. (2007). A future global economy to be built by BRICs, Global Finance Journal, 18: 143-156, doi:10.1016/j.gfj.2006.04.003, http://dx.doi.org/10.1016/10.1016/j.gfj.2006.04.003

Culem, C. G. (1988). The locational determinants of direct investments among industrialized countries, European Economic Review, 32, 885-904, doi:10.1016/0014-2921(88)90051-7, http://dx.doi.org/10.1016/0014-2921(88)90051-7

Dasgupta, D. \& Ratha. D. (2000). The role of short-term debt in recent crises, Finance and Development, Vol. 37, pp. 54-57.

Dunning, J., H. (1981). International production and multinational enterprise, Allen \& Unwin, Vol. 35, pp. 149-66,.

Dunning, J., H. (1993). The Theory of Transnational Corporations. Routledge, London, 16-18.

Durán, J., E. (1999). Los determinantes de la ied en los países de américa latina y el caribe: su impacto sobre el comercio y la integración regional, ECLAC, Mimeo.

Garibaldi, P., Mora, N., Sahay, R. and Zettelmeyer, J. (2002). What moves capital to transition economies?, IMF working paper, WP/02/64.

Hausman, J., A. (1978). Specification tests in econometrics, Econometrica, Vol. 46, pp1251- 71, doi:10.2307/1913827, http://dx.doi.org/10.2307/1913827

Holland, D. \& Pain, N. (1998). The diffusion of innovations in central and eastern europe: a study of the determinants and impact of foreign direct investment, NIESR Discussion Paper No.137, National Institute of Social and Economic Research, London.

Hsiao, C. (1985). Benefits and limitations of panel data, Econometric Reviews, 4(1). 121-174, doi:10.1080/07474938508800078, http://dx.doi.org/10.1080/07474938508800078

Hsiao, C. (1986). Analysis of panel data, Cambridge University Press, Cambridge, UK.

Kearney, A., T. (2005). FDI confidence index, International Journal of Business Economy', Vol. 65, pp. 249-66 Alexandria.

Kose, Ayhan, Eswar, Prasad, Kenneth, Rogoff, \& Shang-Jin, Wei, (2009). Financial Globalization: A Reappraisal, Staff Papers, International Monetary Fund, Vol. 56 (1). pp. 8-62.

Lankes, H., P. and Venables, A., J. (1996). Foreign Direct Investment in Economic Transition: TheChanging Pattern of Investments, Economics of Transition, Vol.4, pp.331-347, doi:10.1111/j.1468-0351.1996.tb00176.x, http://dx.doi.org/10.1111/j.1468-0351.1996.tb00176.x

Libor, Krkoska. (2001). Foreign direct investment financing of capital formation in Central and Eastern Europe, European Bank for Reconstruction and Development Working paper No. 67.

Lipsey, R., E. (2000). Interpreting developed countries' foreign direct investment, NBER Working paper No. 7810.

Mody, Ashoka \& Antu, P., Murshid, (2005). Growing Up With Capital Flows, Journal of International Economics, Vol. 65, pp. 249-66, doi:10.1016/j.jinteco.2004.02.003, http://dx.doi.org/10.1016/j.jinteco.2004.02.003

Narayanamurthy, V., Perumal S., \& Kode Chandra, S., R. (2010). Determinants of FDI in BRICS Countries: A panel analysis, Int. Journal of Business Science and Applied Management, Volume 5, Issue 3. 
Nunes, C., L., Oscategui, J. \& Peschiera, J. (2006). Determinants of FDI in Latin America, Documento De Trabajo 252.

Resmini, L. (2000). The determinants of foreign direct investment into the CEECs: new evidence from sectoral patterns, Economics of Transition, Vol. 8(3). pp. 665- 689, doi:10.1111/1468-0351.00060, http://dx.doi.org/10.1111/1468-0351.00060

Sahoo, P. (2006). Foreign Direct Investment in South Asia: Policy, Trends, Impact and Determinants, ADB Institute Discussion paper No. 56.

Wan Xueli, (2010). FDI in BRIC, International Journal of Business and Management, Volume 5, No 2, Feb. www.imf.org

www.worldbank.org

Zheng P. (2009). A comparison of FDI determinants in China and India, Thunderbird International Business review, Vol. 51, No. 3, May/June, doi:10.1002/tie.20264, http://dx.doi.org/10.1002/tie.20264

Table 3.1. UNCTAD's classification of FDI determinant

\begin{tabular}{|l|l|}
\hline Determining variables & Examples \\
\hline Policy variables & $\begin{array}{l}\text { Tax policy, trade policy, privatization policy, } \\
\text { macroeconomic policy }\end{array}$ \\
\hline Business variables & Investment incentives \\
\hline Market-related economic determinants & Market size, market growth, market structure \\
\hline Resource-related economic determinants & Raw materials, labor costs, labor productivity \\
\hline Efficiency-related economic determinants & Transport and communication costs, labor \\
\hline
\end{tabular}

Source: www.unctad.org

Table 5.1. Descriptive statistics of determinants and FDI

\begin{tabular}{|l|c|c|c|c|c|c|c|c|}
\hline & Obs. & Mean & Median & Max. & Min. & Std. Dev & Skewness & Kurtosis \\
\hline LFDI & 113 & 9.57 & 9.51 & 11.16 & 6.75 & 0.92 & -0.59 & 3.05 \\
\hline INFL & 104 & 132.55 & 8.76 & 2947.73 & -7.63 & 435.61 & 4.55 & 24.81 \\
\hline INFREX & 115 & 104.38 & 105.30 & 122.95 & 30.91 & 10.71 & -5.19 & 36.40 \\
\hline LGCF & 126 & 1.40 & 1.37 & 1.67 & 1.71 & 0.13 & 0.24 & 1.84 \\
\hline LGDP & 126 & 11.65 & 11.60 & 12.69 & 10.98 & 0.35 & 0.63 & 3.0 \\
\hline LLAB & 116 & 8.26 & 8.20 & 8.89 & 7.66 & 0.42 & 0.14 & 1.30 \\
\hline LWAGE & 114 & 9.25 & 9.38 & 10.69 & 7.46 & 0.79 & -0.41 & 2.71 \\
\hline TRAO & 126 & 0.31 & 0.24 & 1.10 & 0.90 & 0.18 & 1.23 & 4.64 \\
\hline
\end{tabular}

Table 5.2. Correlation of variables in study

\begin{tabular}{|l|c|c|c|c|c|c|c|}
\hline & INFL & INFREX & LGCF & LGDP & LLAB & LWAGE & TRAO \\
\hline INFL & 1 & & & & & & \\
\hline INFREX & -0.0615 & 1 & & & & & \\
\hline LGCF & -0.13768 & 0.115565 & 1 & & & & \\
\hline LGDP & -0.08838 & -0.22683 & 0.480151 & 1 & & & \\
\hline LLAB & -0.32949 & 0.242459 & 0.818316 & 0.31702 & 1 & & \\
\hline LWAGE & -0.23393 & -0.13988 & 0.280082 & 0.5891 & 0.467255 & 1 & \\
\hline TRAO & -0.23022 & -0.14971 & 0.410142 & 0.536349 & 0.169026 & 0.390179 & 1 \\
\hline
\end{tabular}


Table 5.3. Determinants of FDI inflows: Panel Data Estimation results based on Random Effects (RE) and Ordinary Least Square Models

\begin{tabular}{|l|c|c|c|c|c|c|}
\hline \multirow{2}{*}{ variables } & \multicolumn{3}{|c|}{ RE } & \multicolumn{2}{c|}{ OLS } \\
\cline { 2 - 7 } & Coeff. & $t$-Statistics & $P$ value & Coeff. & $t$-Statistics & $P$ value \\
\hline INFL & -0.0002 & -2.59 & 0.01 & -0.0002 & -1.62 & 0.10 \\
\hline INFREX & 0.0085 & 2.47 & 0.01 & 0.0109 & 2.68 & 0.00 \\
\hline LGCF & -0.4067 & -0.64 & 0.51 & -0.6218 & -0.69 & 0.49 \\
\hline LGDP & 2.8942 & 18.63 & 0.00 & 2.9179 & 12.97 & 0.00 \\
\hline LLAB & -0.0358 & -0.17 & 0.86 & -0.0526 & -0.17 & 0.85 \\
\hline LWAGE & -0.4974 & -6.96 & 0.00 & -0.4122 & -3.99 & 0.00 \\
\hline TRAO & 1.0416 & 4.08 & 0.00 & 1.3015 & 3.47 & 0.00 \\
\hline Adj. $\mathbf{R}^{2}$ & \multicolumn{7}{|c|}{0.77} & & 0.79 & \\
\hline
\end{tabular}

Table 5.4. Hypothesis test result

\begin{tabular}{|c|l|c|}
\hline $\begin{array}{c}\text { Hypothesis } \\
\text { No. }\end{array}$ & \multicolumn{1}{|c|}{ Hypothesis Statement } & Result \\
\hline 1 & Larger market size of the host country attracts more FDI. & Accepted \\
\hline 2 & Stable macroeconomic condition with high and sustained growth rates attract FDI to the host country. & Accepted \\
\hline 3 & More liberal policies and trade facilities presents opportunity for FDI to come to the hosting country. & Accepted \\
\hline 4 & $\begin{array}{l}\text { An established and advance infrastructure facility of the host country provides great platform for investment and } \\
\text { leads to greater FDI inflow. }\end{array}$ & Accepted \\
\hline 5 & Lower labour cost in the host country pulls FDI to the country. & Accepted \\
\hline 6 & $\begin{array}{l}\text { High Gross capital formation shows the potential of the country for spending and thus has a significant impact on } \\
\text { FDI inflow. }\end{array}$ & Rejected \\
\hline
\end{tabular}

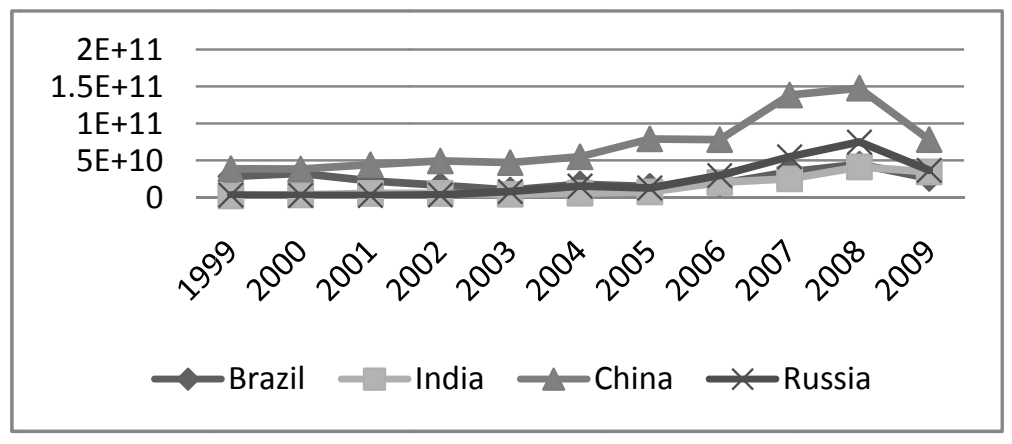

Fig 1.1. Aggregate FDI Inflow in BRIC

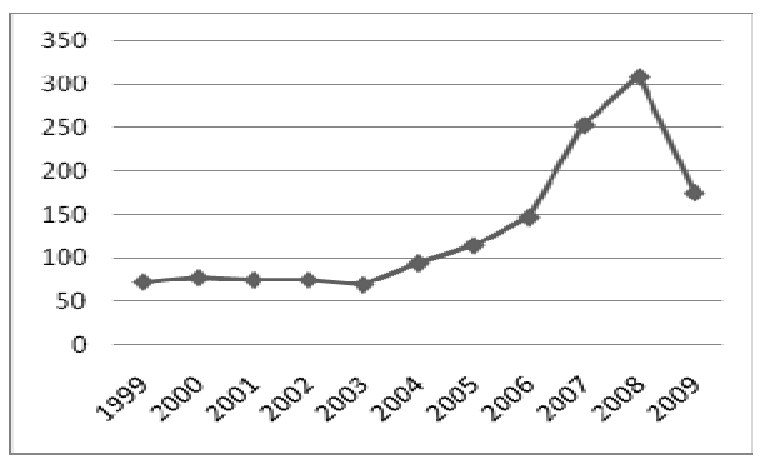

Fig 1.2. Individual FDI Inflow in BRIC countries 